\title{
Do Firms Prefer One Form of Accounting Gimmick Over Other to Meet Peer Performance?
}

\author{
MANISH BANSAL
}

\begin{abstract}
The current study explores whether firms engage in classification shifting to meet industry-average profitability. The study examines the different alternatives under classification shifting for meeting industry numbers. Based on a sample of 15,616 firm-years, results exhibit that firms misclassify the cost of goods sold as a non-operating expense to meet the industry's average gross margin ratio. Further empirical evidence provides that firms prefer shifting expenses over shifting revenues to meet the industry's average profitability. Overall, results imply that peer performance is an important benchmark, and firms strive to achieve the same by engaging in different shifting strategies. The study is among the pioneering attempts that document a form of classification shifting where gross profit and core earnings both change as an effect of misclassification. The findings have important implications for auditors, investors, and analysts.
\end{abstract}

Keywords: Earnings management; classification shifting; revenue misclassification; expense misclassification; industry profitability.

\section{INTRODUCTION}

Earnings management involves the alteration of financial statements either to mislead stakeholders towards the firm's underlying performance or to influence contractual outcomes that depend on reported accounting numbers (Healy \& Wahlen 1999). Classification shifting, a form of earnings management, has got greater attention from researchers and the academic fraternity in the last decade due to an increasing trend among firms to disclose core earnings ${ }^{1}$ separately in the financial statements (Zalata \& Roberts 2016). Under classification shifting, managers deliberately misclassify income statement line items to report favorable operating performance of the firm.

The importance of reporting favorable operating performance has led firms to engage in a variety of misclassification such as shifting of operating expenses to special items (Fan et al. 2010; McVay 2006); extraordinary items (Barnea et al. 1976); discontinued operations (Barua et al. 2010), non-recurring items (Athanasakou et al. 2009), and amongst segments within a firm (Lail et al. 2014). In addition to shifting expenses, firms are found to be engaged in shifting non-operating revenues to operating revenues (Bansal et al. 2021; Malikov et al. 2018).

Further studies expand the scope of shifting practices by finding that firms engage in classification shifting not only to inflate core earnings but also to inflate gross profits $^{2}$ (Poonawala \& Nagar 2019; Fan \& Liu 2017). Like core earnings, gross profits are important performance metrics that signal the operational efficiency of the firm (Weygandt et al. 2005). Gross profits, being a closer figure to sales, have important implications for investors (Fairfield et al. 1996). The recent evidence in Apple Inc. indicates the importance of gross profit metrics. The investors of Apple Inc. raise their concern over the company's shrinking gross margin ratio which has fallen to 36.9 percent in July 2013 from its peak of 47 percent in March 2012. ${ }^{3}$ Among anecdotal evidence, Fischer Imaging Corporation has been found guilty of misclassifying operating costs such as labor and overhead expenses as other operating expenses for reporting inflated gross profits (Accounting and Auditing Enforcement Release No. 2134 on November 15, 2004). The academic pieces of evidence (Poonawala \& Nagar 2019; Fan \& Liu 2017) report that firms engaged in misclassifying COGS as operating and non-operating expenses for meeting gross profit benchmarks.

This evidence implies that firms have significant incentives to manipulate gross profits, yet it does not gain enough attention from the researchers' community. Therefore, it is an under-researched topic. The existing evidence on gross profit manipulation documents that firms engage in shifting COGS to operating expenses to meet prior' period gross profits. However, it keeps the core earnings constant. The empirical evidence on core earnings manipulation suggests that firms have strong incentives to report inflated core earnings (Fan et al. 2010; McVay 2006). Hence, it naturally raises a question: Do firms engage in classification shifting practices in a way that can inflate gross profits as well as core earnings? Therefore, based on the critical assumption that financial statement users, in general, care about gross profits as well as core earnings, we posit that firms are more likely to misclassify COGS as non-operating expenses rather than operating expenses. It enables them to achieve multiple objectives such as reporting the operating profit ${ }^{4}$ as well as gross profit at the inflated amount by misclassifying COGS as a non-operating expense. 
Yamaguchi (2020) reports that firms operating below the industry's average profitability are more likely to be engaged in earnings management to beat the average profitability of the industry. We extend this line by hypothesizing that firms operating below the industry's average gross margin ratio (GMR) are more likely to be engaged in managing gross profits through classification shifting. Like gross profits, GMR can also be manipulated either by decreasing COGS through expense misclassification or by increasing sales through revenue misclassification. However, the relative advantage of shifting expenses is more as compared to shifting revenues for stimulating profitability ratios. Hence, we posit that firms operating below the industry's average GMR are more likely to be engaged in shifting expenses rather than shifting revenues because expense shifting has a greater relative advantage in inflating the gross margin ratio.

We examine these research questions under the Indian institutional settings due to the following reasons. First, the scope of misclassifying expense and revenue items is more for Indian firms due to aggregated form of income statement (Schedule VI, Companies Act, 2013). Second, Indian firms are found to have higher shifting practices after the adoption of International Financial Reporting Standards (Bansal et al. 2021). Third, India has been featured as the nation with weaker corporate governance mechanisms and low investor protection, which in turn is likely to increase the likelihood of a firm's engagement in shifting practices (Narayanaswamy et al. 2012).

Based on a sample of Bombay Stock exchangelisted firms, we find a positive association between non-operating expenses and unexpected gross profits, suggesting that firms misclassify COGS as non-operating expenses for inflating gross profits. Besides, results establish that firms operating below the industry's average gross margin ratio are more likely to be engaged in expense shifting rather than revenue shifting for stimulating GMR. It implies that firms prefer the shifting tool with greater relative advantage. We also find that firms misclassify COGS as a non-operating expense rather than an operating expense. It may be due to the dual advantage of such misclassification as it enables firms to record core earnings as well as gross profit at an inflated amount.

This study has several contributions. First, it adds to the existing literature on classification shifting by extending the work done by Poonawala and Nagar (2019) on gross profit manipulation. While they explored a form of shifting where gross profit was manipulated while keeping core earnings constant. We explore a form of shifting where gross profit and core earnings both change as an effect of misclassification. Second, the study controls the impact of other tools of earnings management, namely real earnings management (REM), accrual-based earnings management, (AEM), and revenue shifting (RS), which was not done in prior studies on gross profit manipulation (Poonawala \& Nagar 2019; Fan \& Liu 2017). Gross profits can be inflated by the AEM, REM, or RS. Hence, to correctly examine the existence of misclassification for gross profit manipulation, it is a must to control the impact of these tools. Third, this study explores whether firms prefer shifting expenses over shifting revenue to meet the industry's average gross margin ratio. The advantage in terms of inflating the GMR by recording lower COGS by expense shifting is more than recording higher sales by revenue shifting for a given magnitude of misclassification. Hence, firms are found to prefer one form of accounting gimmicks over another to meet peer performance.

This study proceeds as follows. In the next section (section 2), we present the literature on classification shifting whereas section 3 covers the discussion on hypotheses development. Section 4 describes the research design and section 5 describes the sample selection and empirical results. We conclude the paper with the discussion and conclusion in section 6 .

\section{LitERATURE REVIEW}

Prior literature addressed three tools of earnings management, namely accrual-based earnings management (Kothari et al., 2005; Dechow et al., 1995), real earnings management (Zang, 2012; Gunny 2010; Roychowdhury 2006), and classification shifting (Haw et al., 2011; Fan et al., 2010; McVay, 2006). Under AEM, managers increase or decrease the current period earnings by borrowing or pushing the earnings from/ to future period earnings through the use of discretionary accruals. Under REM, managers are deviating from the normal course of business activities such as excessive price discounts to inflate current year sales revenue; overproduction to reduce the COGS, or cutting research and development expenses (Roychowdhury, 2006) to inflate net income. Classification shifting represents a method under which managers engage in the vertical movement of items within the income statement to portray the favorable operating performance of the firm.

The literature on classification shifting has been evolved after 2006, with the first evidence given by McVay (2006), where U.S firms are found to be engaged in shifting of core expenses to income-decreasing special items to report inflated core earnings. Further, Fan et al. (2010) support McVay's findings by taking quarterly data on special items. Other studies expand the scope of shifting of core expenses to items other than special items i.e. firms are found to be engaged in shifting of core expenses to extraordinary items (Barnea et al., 1976); to discontinued operations (Barua et al., 2010), nonrecurring items (Al-Haddad et al., 2019), and amongst segments within firms (Lail et al., 2014). Nagar and Sen (2016) find another form of shifting, where firms are found to be engaged in netting income-increasing special items against their core expenses to record inflated core earnings. Other than expense misclassification, studies show evidence of revenue misclassification, where firms shift non-operating revenues to operating revenues (Malikov et al., 2018). 
The scope of classification shifting is likely to be increased after the adoption of International Financial Reporting Standards (IFRS). India has adopted the path of convergence rather than big-bang adoption. India converged its domestic accounting principles (Indian Generally Accepted Accounting Principles) in line with IFRS. This converged form of standards is referred to as Indian Accounting Standards (Ind AS). Ind AS itself implies allowable differences in the presentation and disclosure of items. For instance, firms are required to disclose revenue under two heads only, namely "revenue from operations", and "other income" and that also in an aggregated form. Besides, there is less mandatory disclosure requirement for recoding non-recurring expenses under Ind AS, which in turn, likely to increase the scope and opportunities for managers to misclassify expenses. The vast categories of expenses under the nonoperating head are also likely to provide greater ease for expense misclassification. Under Indian Institutional settings, the magnitude of earnings management and shifting practices is increased after the adoption of Ind AS (Bansal et al., 2021; Bansal \& Garg, 2021).

\section{Hypotheses DeVElopMENT}

The existing studies on gross profit manipulation indicate that firms inflate gross profits in two different ways. First, as documented by Poonawala and Nagar (2019), where firms are found to be engaged in shifting COGS to operating expenses. However, it keeps the core earnings constant. Prior studies on core earnings manipulation show that firms have significant incentives to report inflated core earnings, and they are found to be engaged in shifting core expenses to non-operating expenses (Fan et al., 2010; McVay, 2006). Hence, firms must look for shifting the COGS in such a way that inflates core earnings too.

The second evidence on gross profit manipulation was found by Fan and Liu (2017). They find that firms shift COGS to income-decreasing special items. It is not an easy way of shifting due to the non-recurring nature of special items (Revsine et al., 2005). The shifting of COGS to special items is not a viable option for firms in some situations. Shifting core expenses to special items may be more detectable if there are no other naturally occurring income-decreasing special items, such as merger-related costs, restructurings, or certain asset sales. The presence of these naturally occurring special items may be needed to camouflage misclassified COGS. Special items heighten the concerns of investors, analysts, and auditors about the use of special items to manage earnings (Cready et al., 2010; Kolev et al., 2008). These items are usually of larger magnitude; hence the recording of special items is a red flag to investors about the financial instability of the business. Investors and auditors are expected to critically evaluate the component of special items. Therefore, it is expected that investors' greater attention towards special items restricts the manager's behavior of misclassifying COGS as special items.

If firms shift COGS to non-operating expenses, it is relatively easier as well as more advantageous for firms. Firms can record both gross profits as well as core earnings at an inflated amount by shifting COGS to nonoperating expenses, hence it relatively more advantageous practice. Also, the vast categories of expenses under the non-operating head provide greater ease to misclassify COGS as non-operating expenses. Accordingly, we build our first hypothesis as follows:

$\mathrm{H}_{1}$ : Managers are more likely to misclassify the cost of goods sold as non-operating expenses rather than operating expenses.

Gross profits, being an absolute measure cannot be used for comparing a firm's performance in the industry. Gross margin ratio (GMR), a relative measure is used for inter-firm comparison. Higher GMR indicates the availability of more profits with the firm to cover its operating and non-operating costs. Firms operating above the industry's average GMR are considered to be highperforming firms. Compared with the industry average, a lower margin could indicate a firm is under-pricing. Firms are more likely to manipulate earnings to avoid negative market reactions (Athanasakou et al. 2011). Analysts use gross profit margin to compare a company's business model with that of its competitors. A lower ratio indicates the inefficiency of firms concerning the purchase and sales policy.

Like gross profits, GMR can also be manipulated either by reducing expenses or increasing revenues through shifting. However, the relative advantage of shifting expenses is more as compared to shifting revenues to stimulate GMR. For instance, we assume the firm's current GMR is 40 percent (Sales $\$ 1000$, COGS $\$ 600$ ), and the industry's gross margin ratio is above 60 cents. Firms have two alternatives to stimulate GMR. Alternative 1: Firms can shift the non-operating revenue of $\$ 200$ to sales, then the ratio becomes 50 percent (Sales \$ 1200, COGS \$ 600). Alternative II: Firms can shift COGS \$ 200 to non-operating expenses, the ratio becomes 60 percent (Sales 1000, COGS \$400). Hence, if firms shift revenues and expenses with the same magnitude, the relative advantage of expense shifting is more. Therefore, we posit firms operating below the industry's average GMR are more likely to engage in expense shifting due to its relatively greater advantage in terms of reporting higher GMR. Based on the above discussion, we build our second hypothesis as follows:

$\mathrm{H}_{2}$ : Ceteris paribus, firms operating below the industry's average profitability are more likely to engage in expense shifting rather than revenue shifting. 


\section{RESEARCH DESIGN}

We estimate unexpected gross profits by employing the model used by Poonawala and Nagar (2019) developed on McVay's core earnings expectation model (McVay 2006). Unexpected gross profits are measured as the difference between actual gross profits and expected gross profits, where the latter is estimated through coefficients of the following model (1).

$$
\begin{aligned}
G P_{i, t}= & \beta_{0}+\beta_{1}\left(1 / A T_{i, t-1}\right)+\beta_{2} G_{i, t-1}+\beta_{3} A C C_{i, t}+\beta_{4} A C C_{i, t-1} \\
& +\beta_{5} \text { Sales }_{i, t}+\beta_{6} \Delta \text { Sales }_{i, t}+\beta_{7} \text { Neg_dSales }_{i, t}+\varepsilon_{i, t}
\end{aligned}
$$

Where GP is gross profits computed as sales minus cost of goods sold. $A C C$ is accruals measured as the difference between net income before extraordinary items and cash flows from operating activities. Although IFRS has removed the reporting of extraordinary items, however, Indian authorities have converged their domestic GAAP in line with IFRS, hence the prowess database provides the data on net income before extraordinary items because firms are allowed to record the same under IFRSconverged standards. This feature is unique to Indian firms because of the different economic environments. Hence, we use the net income before taking into account the impact of these extraordinary items while estimating the accrual component of earnings. Sales are revenue from operations. $\triangle$ Sales is a change in sales from period t-1 to $t$. NEG_ASales is a dummy variable that takes value equals to one if $\Delta$ Sales is negative, and 0 otherwise. See Table 1 for detailed variables definition and measurement. The residual serves as the proxy for the unexpected gross profits.

To test our first hypothesis that firms engage in shifting of COGS to non-operating expenses to report inflated gross profits, we run the following regression model (2). As the firms can shift COGS to any one category of expenses or both categories, namely operating expenses, and non-operating expenses; therefore we regress unexpected gross profits with both non-operating expenses and unexpected operating expenses. Our main regression model is as follows:

$$
\begin{aligned}
U E_{G P}= & \beta_{0}+\beta_{1} N O E_{i, t}+\beta_{2} U E_{O E_{i, t}}+\beta_{3} A_{C F O_{i, t}} \\
& +\beta_{4} A_{P R O D_{i, t}}+\beta_{5} A_{D I S X_{i, t}}+\beta_{6} A_{A C C_{i, t}}+ \\
& +\beta_{7} R S_{i, t}+\beta_{8} S I Z E_{i, t}+\beta_{9} L E V_{i, t}+ \\
& \beta_{10} S G_{i, t}+\gamma_{t}+\delta_{j}+\varepsilon_{i, t}
\end{aligned}
$$

Where $U E_{-} G P$ is unexpected gross profit, measured as residuals from the model (1). NOE is non-operating expenses. $U E \_O E$ is an unexpected operating expense (see Appendix for the measurement of $U E \_O E$ ). Our first hypothesis predicts a positive coefficient of $N O E$ if firms engage in the shifting of COGS to non-operating expenses for inflating gross profits. Unlike prior studies (Poonawala \& Nagar 2019; Fan \& Liu 2017), we control for determinants of unexpected gross profits.
We control the impact of REM, AEM, and revenue shifting (hereafter RS) while examining expense shifting because firms are found to be engaged in multiple tools while manipulating earnings (Abernathy et al. 2014). Therefore, it is a must to control the impact of these tools to correctly measure the existence of COGS misclassification for inflating gross profits. We include proxies of REM, $A E M$, and $R S$ as main effects with our main variables of interest in our model (2).

Consistent with the prior studies (for instance, Bansal and Kumar, 2021; Bansal and Ali, 2021; Zang 2012; Cohen \& Zarowin 2010), we use three proxies of REM, namely $A_{-} C F O, A_{-} D I S X$, and $A_{-} P R O D$ shows an abnormal level of cash flow from operations, abnormal level of discretionary expenses and abnormal level of production costs, respectively. Consistent with the prior studies (for instance, Shah et al., 2020; Sivanandan \& Wahab, 2020; Al-Jaifi, 2017; Malik \& Ahmad, 2017), we use discretionary accruals to measure AEM. We follow Kothari et al. (2005) to determine discretionary accruals, denoted by $A \_A C C$. We include RS, a measure of revenue shifting where RS is equal to one for firms with positive unexpected operating revenue (UE_OR), and zero otherwise. A positive value of $U E_{-} O R$ implies that firms shift non-operating revenue (NOR) to operating revenue (OR). See Appendix for the measurement of REM and $A E M$.

In the second set of control variables, we control for certain firm-specific variables which may affect the level of a firm's gross profits such as size, leverage, and sales growth. We measure size, leverage, and sales growth as the natural logarithm of total assets; the proportion of total outside liabilities to total assets, and percentage change in sales from period $t-1$ to $t$, respectively. The subscript $i$ and $t$ denote firms and year, respectively. $\gamma_{t}\left(\delta_{j}\right)$ (indicate the year (industry) fixed effects, which control for unobserved heterogeneity within the year (industry).

Our second hypothesis states that firms operating below the industry's average gross margin ratio are more likely to engage in expense shifting rather than revenue shifting. The relative advantage of stimulating the gross margin ratio via a shift of expenses is more as compared to the shift of revenues. We use the same model (2) for testing the misclassification of COGS as non-operating expenses (expense shifting) in firms operating below the industry's average gross margin ratio.

Next, to test the existence of revenue shifting in firms operating below the industry's average GMR, we first compute the level of unexpected operating revenue of the firm by following the operating revenue expectation model developed by Malikov et al. (2018). The unexpected operating revenue is measured as the difference between actual operating revenue and expected operating revenue, where the latter is estimated using the coefficients from the following model (3): 


$$
\begin{aligned}
\frac{O R_{i, t}}{A T_{i, t-1}}= & \alpha_{0}+\beta_{1} \frac{1}{A T_{i, t-1}}+\beta_{2} \frac{O R_{i, t-1}}{A T_{i, t-2}}+ \\
& \beta_{3} M T B_{i, t-1}+\beta_{4} \frac{A R_{i, t-1}}{A T_{i, t-2}}+ \\
& \beta_{5} \frac{A R_{i, t}}{A T_{i, t-1}}+\varepsilon_{i, t}
\end{aligned}
$$

where OR is operating revenues, measured as sales revenue. All these variables are scaled by lagged total assets. The inverse of lagged total assets (1/ Assets) is included as another control variable that provides additional control for heteroskedasticity. The subscript $i$ and $t$ represent firm and year, respectively. See Table 1 for variable definition and measurement. Residuals $\left(\varepsilon_{i, t}\right)$ measures unexpected operating revenues. Our focus is on the unexpected operating revenue, as it is the dependent variable for testing our hypothesis 2 .

To check whether firms engage in shifting of revenues, we use the following regression model (4), where we regress non-operating revenues on unexpected operating revenue, where the latter is measured as residuals from the model (3).

$$
\begin{aligned}
U E_{O R_{i, t}}= & \beta_{0}+\beta_{1} N_{O R_{i, t}}+\beta_{2} A_{C F O_{i, t}} \\
& +\beta_{3} A_{P R O D_{i, t}}+\beta_{4} A_{D I S X_{i, t}}+ \\
& \beta_{5} A_{A C C}+\beta_{6} S_{i, t} E_{i, t}+\beta_{7} L E V_{i, t} \\
& +\beta_{8} S G_{i, t}+\gamma_{t}+\delta_{j}+\varepsilon_{i, t}
\end{aligned}
$$

Where, UE_OR is unexpected operating revenues, measured as residuals from the model (3). NOR is nonoperating revenues. We include both sets of control

\begin{tabular}{|c|c|}
\hline Variables & Definition \& measurement \\
\hline$G P$ & Gross profits, calculated as sales minus cost of goods sold. \\
\hline$T A$ & Total assets of the firm. \\
\hline$A C C$ & $\begin{array}{l}\text { Accruals, calculated as net income before extraordinary items and discontinued operations minus cash flow } \\
\text { from operations }\end{array}$ \\
\hline Sales & Sales revenue of a firm. \\
\hline$\Delta$ Sales & Change in sales from the prior period to the current period. \\
\hline Neg_sSales & The negative change in sales from the prior period to the current period, and zero otherwise. \\
\hline$U E_{-} G P$ & Unexpected gross profits are measured as residuals from the model (1). \\
\hline NOE & $\begin{array}{l}\text { Non-operating expenses, measured as the difference between core earnings plus non-operating income minus } \\
\text { and bottom-line earnings. }\end{array}$ \\
\hline$O E$ & Operating expenses, calculated as the difference between gross profits and core earnings. \\
\hline$M V$ & Log of the market value of the firm. \\
\hline Tobin $Q$ & Measured as a proportion of market value to assets value of the firm. \\
\hline$I N T$ & Retained earnings of the firm. \\
\hline$U E \_O E$ & Unexpected operating expenses measured as residuals from the model (1) shown in Appendix. \\
\hline $\mathrm{CFO}$ & Cash flows from operations \\
\hline A_CFO & Abnormal levels of cash flow from operations derived using the Roychowdhury (2006), model \\
\hline$P R O D$ & Production costs, calculated as the sum of the cost of goods sold and change in inventory \\
\hline$A_{-} P R O D$ & Abnormal levels of production costs derived using the Roychowdhury (2006) model \\
\hline DISX & Discretionary expenses, calculated as the sum of selling, general, and administrative and R\&D expenses \\
\hline A_DISX & Abnormal levels of discretionary expenses derived using the Roychowdhury (2006) model \\
\hline$\Delta R e c$ & Change in account receivables \\
\hline$P P E$ & The gross value of property, plant, and equipment \\
\hline A_ACC & $\begin{array}{l}\text { Abnormal levels of accruals derived using the performance adjusted modified Jones (1991) model (Kothari et } \\
\text { al. 2005) }\end{array}$ \\
\hline OR & Operating revenues, defined as sales revenue. \\
\hline$M T B$ & The ratio of the market value of equity to book value of equity. \\
\hline$A R$ & Accounts receivable. \\
\hline$U E \_O R$ & Unexpected operating revenues measured as residuals from model (3). \\
\hline
\end{tabular}
variables as used in model (2). We expect $\beta_{1}$ to be negative if firms operating below the industry's average gross margin ratio are engaged in shifting of non-operating revenues to operating revenues. All the variables are defined in Table 1.

TABLE 1. Variables definition 


\begin{tabular}{|c|c|}
\hline$R S$ & RS is equal to one for firms that have positive unexpected operating revenues (UE_OR), and zero otherwise. \\
\hline SIZE & Natural logarithm of total assets. \\
\hline$L E V$ & The proportion of total outside liabilities to total assets. \\
\hline$S G$ & Sales growth, measured as the percentage change in sales from period t- 1 to $t$. \\
\hline NOR & $\begin{array}{l}\text { Non-operating revenues include dividend income, rent received, interest received, gain from the sale of } \\
\text { foreign exchange, and all other income from investing and financing activities. }\end{array}$ \\
\hline$W C A$ & $\begin{array}{l}\text { Working capital accruals, measured as increase in accounts receivable plus increase in inventory minus } \\
\text { decrease in accounts payable minus decrease in income taxes payable plus increase in other current assets. }\end{array}$ \\
\hline
\end{tabular}

\section{RESULTS}

Our sample is comprised of Indian firms listed on the Bombay Stock Exchange (BSE). Data has been obtained from the Centre for Monitoring Indian Economy's (CMIE) Prowess database and spans over eight financial years ending in March 2012 to March 2019. The data on expense shifting and revenue shifting is significantly missing before the financial year ended March 2012 due to misreporting and delayed adoption of International Financial Reporting Standards in India. Hence, we initiate our analysis from the financial year 2012 due to sufficient availability of data for measuring expense and revenue shifting. Our initial sample consists of 37,248 firm-years (4,656 firms). Following prior studies, we exclude financial and utility firms because the former has a different financial reporting environment, and the latter has more predictable earnings growth. We are left with a sample of 29,264 firm-years (3,658 firms) after excluding the financial firms, utility firms, and firms with negative sales or net worth from our initial sample. Further, we exclude firms with missing data for measuring our three main variables used in this study i.e unexpected gross profits, non-operating expenses, and unexpected operating expenses. Finally, we are left with a sample of 15,616 firm-years (1952 firms) for testing our hypotheses.

Table 2 indicates the descriptive statistics for the main variables. The mean of unexpected gross profits (UE_GP), as expected, is positive (0.005), implying that firms recorded gross profit more than the expected amount. The median (mean) of non-operating expenses (NOE) is 0.048 $(0.052)$ and the median (mean) of unexpected operating expenses (UE_OE) is $-0.024(0.006)$. The median (mean) of non-operating expenses (NOE) is higher than the corresponding figure of unexpected operating expenses (UE_OE). The median (mean) of unexpected operating revenues $\left(U E \_O R\right)$ is $-0.043(-0.012)$ and the median (mean) of non-operating revenues (NOR) is $0.015(0.030)$. Besides, the mean of abnormal level of cash flows from operations $\left(A_{-} C F O\right)$, an abnormal level of discretionary expenses $\left(A \_D I S X\right)$ i.e., 0.013 and 0.001 implies that firms engage in real earnings manipulations. The average frequency of revenue shifting $(R S)$ is 0.492 , which indicates that around fifty percent of firms are engaged in shifting of revenues and have positive unexpected operating revenues.

TABLE 2. Descriptive statistics

\begin{tabular}{ccccccc}
\hline Variables & Mean & $25^{\text {th }}$ & Median & $75^{\text {th }}$ & SD & $\mathrm{N}$ \\
\hline UE_GP & 0.005 & -0.043 & -0.003 & 0.043 & 0.130 & 15,616 \\
NOE & 0.052 & 0.026 & 0.048 & 0.069 & 0.049 & 15,616 \\
UE_OE & 0.006 & -0.079 & -0.024 & 0.054 & 0.170 & 15,616 \\
UE_OR & -0.012 & -0.406 & -0.043 & 0.340 & 0.687 & 14,272 \\
NOR & 0.030 & 0.006 & 0.015 & 0.033 & 0.077 & 14,272 \\
A_CFO & 0.013 & -0.093 & -0.004 & 0.081 & 0.671 & 9,668 \\
A_PROD & -0.005 & -0.121 & -0.013 & 0.091 & 0.452 & 10,767 \\
A_DISX & 0.001 & -0.029 & -0.016 & 0.009 & 0.076 & 8,806 \\
$A_{-} A C C$ & -0.007 & -0.076 & -0.011 & 0.054 & 0.738 & 9,168 \\
$R S$ & 0.492 & 0.000 & 0.000 & 1.000 & 0.500 & 8,390 \\
SIZE & 7.951 & 6.523 & 7.860 & 9.303 & 2.079 & 15,616 \\
LEV & 0.634 & 0.369 & 0.580 & 0.777 & 0.788 & 15,600 \\
$S G$ & 0.677 & -0.065 & 0.062 & 0.189 & 2.796 & 15,616 \\
\hline
\end{tabular}


In Table 3, the values in the lower (upper) diagonal display Pearson (Spearman) correlation coefficients for the main variables. The Pearson (Spearman) correlation coefficient between $U E_{-} G P$ and NOE is 0.156 (0.257), which implies the increase in unexpected gross profits with an increase in non-operating expenses. Both coefficients are statistically significant at the $1 \%$ level.
Consistent signs imply that these two variables are also mechanically positively related. The corresponding correlation values between $U E G P$ and $U E \_O E$ is 0.029 $(-0.066)$. The correlation between $U E_{-} O R$ and NOR is $-0.043(-0.029)$, which implies the increase in unexpected operating revenues with a decrease in non-operating revenues.

TABLE 3. Correlation matrix

\begin{tabular}{|c|c|c|c|c|c|c|c|c|c|c|c|c|c|}
\hline les & $-G P$ & $\partial E$ & $O E$ & $U E_{-} O R$ & NOR & $A_{-} C F O$ & $A_{-} P R O D$ & $A_{-} D I S X$ & $A_{-} A C C$ & $R S$ & SIZE & $L E V$ & $S G$ \\
\hline$U I F G P$ & חOח & 2 & 75 & 6 & 2 & 7 & 0 & 4 & 0 & & 4 & & 0.405 \\
\hline$N O F$ & 6 & 0 & 8 & 3 & 0.003 & 2 & -0.279 & & 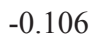 & & 7 & & 0.200 \\
\hline$U E \_O E$ & 29 & 93 & 1.000 & 90 & -0.0 & 983 & 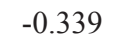 & 08 & .061 & 9 & 0.115 & 37 & -0.150 \\
\hline$O R$ & 0.161 & 2 & 49 & 00 & -0.029 & 07 & -0 & 00 & 3 & & 0.078 & 76 & 0.201 \\
\hline$N O R$ & 053 & 15 & 55 & 43 & 1.000 & -0 . & -0.008 & 6 & 10 & -0 . & 0.063 & & 0.012 \\
\hline$A_{-} C F O$ & -0.049 & 0.095 & 76 & 44 & -0.046 & 1.000 & -0 & 55 & 99 & & 0.042 & & 0.160 \\
\hline A_PROD & -0 & -0.121 & 207 & 77 & 0.021 & -0.068 & 1.000 & & 28 & -0.197 & -0.164 & & -0.287 \\
\hline$A \_D I S X$ & 0.073 & 0.046 & 0.249 & 73 & -0.0 & 0.093 & -0.106 & 1.000 & 0.001 & 0.177 & 0.285 & & 0.165 \\
\hline$A \_A C C$ & & & & & & & & & & & & & 0.030 \\
\hline$R S$ & & & 3 & & & & & & & & 0.075 & & 0.163 \\
\hline SIZE & 0.035 & 0.092 & -0.071 & -0.002 & 0.025 & -0 . & -0 . & & 75 & & 1.000 & 6 & 0.057 \\
\hline$L E V$ & -0.020 & 0.217 & 0.039 & 0.046 & -0.053 & 0.072 & 0.017 & 0.006 & -0.609 & 0.030 & -0.021 & 1.000 & 0.105 \\
\hline$S G$ & 0.009 & 0.035 & -0.006 & -0.013 & -0.004 & 0.002 & -0.004 & -0.004 & 0.005 & -0.012 & -0.004 & 0.007 & 1.000 \\
\hline
\end{tabular}

Note: The upper(lower) diagonal represents Spearman (Pearson) correlation coefficients. Amounts in bold are significant at the 0.01 level

\section{EFFECT OF COGS MISCLASSIFICATION ON GROSS PROFITS}

Table 4 provides regression results of the model (2) used to investigate whether firms misclassify COGS as operating expenses or non-operating expenses. Our hypothesis predicts a positive association between unexpected gross profits $\left(U E \_G P\right)$ and non-operating expenses $(N O E)$. The coefficient of NOE is positive and statistically significant $\left(\beta_{1}=0.322, \mathrm{p}<0.05\right)$, whereas the coefficient of $U E_{-} O E$ is negative $\left(\beta_{1}=-0.606, \mathrm{p}<0.00\right)$. Hence, the positive association between $U E \_G P$ and NOE supports our first hypothesis that firms are more likely to misclassify COGS as non-operating expenses. Specifically, one standard deviation change in NOE in our sample implies a change of $1.6 \%$ (coefficient of NOE $(0.322)^{*}$ Standard deviation of $N O E(0.05)$ in unexpected gross profits, which is economically meaningful for firms.

Further, to ensure that our results are not because of regressing both categories of expenses i.e., non-operating expenses (NOE) and unexpected operating expenses $\left(U E \_O E\right)$ in one regression model, we run model (2) separately regressing NOE and $U E_{-} O E$ on $U E_{-} G P$. The results (untabulated) show that the coefficient of $N O E$ is significantly positive under all specifications. Hence, the overall results support our first hypothesis that firms misclassify COGS as non-operating expenses rather than operating expenses.

It may be because of dual advantage and ease in shifting. Firms can report inflated gross profits as well as core earnings by misclassifying COGS as non-operating expenses. Besides, it is relatively easier to shift COGS to non-operating expenses due to vast categories of expenses under the non-operating head. Our results are contrasted to findings of Poonawala and Nagar (2019) where a strong positive association was found between $U E_{-} G P$ and $U E_{-} O E$ suggesting that firms shift COGS to operating expenses for reporting inflated gross profits. The probable reason behind contrast findings may be because of the impact of REM, AEM, and RS, which can be used by the firms to increase sales or decrease COGS, which in turn will inflate gross profits. Unlike Poonawala and Nagar (2019), we control the impact of these other tools of earnings management. 
TABLE 4. The effect of classification shifting of the cost of goods sold

\begin{tabular}{|c|c|}
\hline Variables & $U E_{-} G P($ Model 2) \\
\hline \multirow[t]{2}{*}{ NOE } & $0.322 *$ \\
\hline & $(0.172)$ \\
\hline \multirow[t]{2}{*}{$U E \_O E$} & $-0.606^{* * *}$ \\
\hline & $(0.042)$ \\
\hline \multirow[t]{2}{*}{$A_{-} C F O$} & $-0.033 * * *$ \\
\hline & $(0.004)$ \\
\hline \multirow[t]{2}{*}{$A_{-} P R O D$} & $-0.037 * * *$ \\
\hline & $(0.006)$ \\
\hline \multirow[t]{2}{*}{$A_{-} D I S X$} & $0.244 * * *$ \\
\hline & $(0.037)$ \\
\hline \multirow[t]{2}{*}{$A_{-} A C C$} & 0.002 \\
\hline & $(0.006)$ \\
\hline \multirow[t]{2}{*}{$R S$} & $0.030 * * *$ \\
\hline & $(0.005)$ \\
\hline \multirow[t]{2}{*}{ SIZE } & $-0.004 * *$ \\
\hline & $(0.002)$ \\
\hline \multirow[t]{2}{*}{$L E V$} & $0.027 * * *$ \\
\hline & $(0.005)$ \\
\hline \multirow[t]{2}{*}{$S G$} & $0.010 * * *$ \\
\hline & $(0.001)$ \\
\hline \multirow[t]{2}{*}{ Intercept } & -0.018 \\
\hline & $(0.012)$ \\
\hline Industry effect & Yes \\
\hline Time effect & Yes \\
\hline No. of observations & 5,965 \\
\hline R-sq. & 0.369 \\
\hline $\mathrm{p}$-value & 0.000 \\
\hline
\end{tabular}

Note: Table shows regression results for model (2) examining whether firms engage in expense shifting. Robust standard errors are reported in parentheses. $* * *, * *$ and $*$ indicate significance at $1 \%, 5 \%$, and $10 \%$ (two-tailed) levels, respectively.

EFFECT OF COGS SHIFTING IN FIRMS OPERATING BELOW THE INDUSTRY'S AVERAGE GROSS MARGIN RATIO

Table 5 shows the regression results of model (2) for the firms operating below the industry's average gross margin ratio. The coefficient of NOE $(0.693, \mathrm{p}<0.000)$ is positive and statistically significant at a $1 \%$ level of significance. The results shown in Table 5 have two important observations. First, it supports our initial findings that firms are more likely to misclassify COGS as non-operating expenses rather than operating expenses. Second, the significant positive association between $U E_{-} G P$ and NOE, and a significant negative association between $U E_{-} G P$ and $U E_{-} O E$, implies that firms with a gross margin ratio lower than the industry's ratio are strong shifting COGS to non-operating expenses. It may be because firms operating below the industry's averages are usually smaller in size, and smaller firms are less likely to experience frequent structural changes in their business operations. Smaller firms relative to their larger counterparts have a lesser probability of natural occurrence of non-operating expenses in every financial year. Therefore, we can say that their smaller quantum of non-operating expenses provides them greater opportunities to shift COGS to non-operating expenses. Overall, the results of Table 5 support the first part of our second hypothesis that firms operating below the industry's average gross margin ratio are more likely to engage in expense shifting for stimulating GMR. 
TABLE 5. Testing misclassification of COGS in firms operating below gross margin ratio

\begin{tabular}{|c|c|}
\hline Variables & $U E \_G P($ Model 2) \\
\hline \multirow[t]{2}{*}{$N O E$} & $0.693 * * *$ \\
\hline & $(0.140)$ \\
\hline \multirow[t]{2}{*}{$U E_{-} O E$} & $-0.456^{* * *}$ \\
\hline & $(0.056)$ \\
\hline \multirow[t]{2}{*}{$A_{-} C F O$} & $-0.033 * * *$ \\
\hline & $(0.003)$ \\
\hline \multirow[t]{2}{*}{$A_{-} P R O D$} & $-0.017 * * *$ \\
\hline & $(0.004)$ \\
\hline \multirow[t]{2}{*}{$A_{-} D I S X$} & $-0.209 * * *$ \\
\hline & $(0.037)$ \\
\hline \multirow[t]{2}{*}{$A \_A C C$} & 0.001 \\
\hline & $(0.005)$ \\
\hline \multirow[t]{2}{*}{$R S$} & -0.001 \\
\hline & $(0.001)$ \\
\hline \multirow[t]{2}{*}{ SIZE } & $0.006^{* *}$ \\
\hline & $(0.003)$ \\
\hline \multirow[t]{2}{*}{$L E V$} & $0.003 * * *$ \\
\hline & $(0.001)$ \\
\hline \multirow[t]{2}{*}{$S G$} & $(0.004)$ \\
\hline & $-0.021 *$ \\
\hline \multirow[t]{2}{*}{ Intercept } & $(0.012)$ \\
\hline & Yes \\
\hline Industry effect & Yes \\
\hline Time effect & 5,496 \\
\hline No. of observations & 0.000 \\
\hline $\mathrm{p}$-value & 0.298 \\
\hline Adjusted R-sq. & 0.000 \\
\hline
\end{tabular}

Note: Table shows regression results of model (2) for firms operating below the industry's average gross margin ratio.

EFFECT OF REVENUE SHIFTING IN FIRMS OPERATING BELOW THE INDUSTRY'S AVERAGE GROSS MARGIN RATIO

Table 6 presents the results of the regression model (4) to test the misclassification of revenues. This model provides evidence on whether firms operating below the industry's average gross margin ratio (same set of firms as used in Table 5) are engaged in shifting non-operating revenue to operating revenue. The coefficient of NOR is negative $\left(\beta_{1}\right.$ $=-2.238, \mathrm{p}>0.10)$ implies that firms engage in shifting non-operating revenue to operating revenue; however, this association is not statistically significant. As the firms can inflate their gross margin ratio by shifting NOR to $O R$, therefore the results show the negative coefficient of $N O R$, which implies an increase in $O R$ with a decrease in NOR. However, this association is not strong among firms operating below the industry's average margin ratio.

The significant positive coefficient of NOE on unexpected gross profits (UE_GP) in Table 5, and the insignificant negative coefficient of $N O R$ on unexpected operating revenues (UE OR) in Table 6, implies that firms operating below the industry's average gross margin ratio are more likely to engage in expense shifting rather than revenue shifting for stimulating gross margin ratio. The advantage of recording lower COGS is more than the advantage of recording higher operating revenue for increasing the gross margin ratio. Hence, the results of Table 5 and Table 6 support our second hypothesis that firms are more likely to prefer expense shifting over revenue shifting for stimulating the gross margin ratio.

In the nutshell, our results suggest that firms are more likely to shift COGS to non-operating expenses rather than operating expenses to report inflated gross profits, and firms operating below the industry's average gross margin ratio are more likely to engage in shifting of expenses rather than shifting revenues to stimulate gross margin ratio. It implies that certain firm-specific factors that influence the manager's choice regarding the use of various shifting tools. 
TABLE 6. Testing misclassification of revenues in firms operating below gross margin ratio

\begin{tabular}{|c|c|}
\hline Variables & $U E_{-} O R$ (Model 4) \\
\hline \multirow[t]{2}{*}{ NOR } & -2.238 \\
\hline & $(2.108)$ \\
\hline \multirow[t]{2}{*}{$A_{-} C F O$} & $0.425^{* * *}$ \\
\hline & $(0.067)$ \\
\hline \multirow[t]{2}{*}{$A_{-} P R O D$} & 0.033 \\
\hline & $(0.078)$ \\
\hline \multirow[t]{2}{*}{$A_{-} D I S X$} & -0.534 \\
\hline & $(0.781)$ \\
\hline \multirow[t]{2}{*}{$A \_A C C$} & 0.056 \\
\hline & $(0.082)$ \\
\hline \multirow[t]{2}{*}{ SIZE } & $-0.038^{*}$ \\
\hline & $(0.020)$ \\
\hline \multirow[t]{2}{*}{$L E V$} & -0.262 \\
\hline & $(0.371)$ \\
\hline \multirow[t]{2}{*}{$S G$} & -0.011 \\
\hline & $(0.007)$ \\
\hline \multirow[t]{2}{*}{ Intercept } & -0.018 \\
\hline & $(0.167)$ \\
\hline Industry effect & Yes \\
\hline Time effect & Yes \\
\hline No. of observations & 4,827 \\
\hline $\mathrm{p}$-value & 0.000 \\
\hline Adjusted R-sq. & 0.351 \\
\hline
\end{tabular}

Note: This table shows regression results for examining whether firms operating below the industry's average gross margin ratio engage in classification shifting of revenues.

\section{ROBUSTNESS CHECKS}

We use alternative specifications for expense shifting and revenue shifting to validate our results. For expense shifting, following Fan et al. (2010), we use two alternative specifications for the model (1). First, we replace accruals with trade receivables because gross profits can be inflated by recording excessive sales, and this excessive sale may be due to liberal credit terms allowed to debtors, results in higher trade receivables. Second, we replace accruals with working capital accruals (WCA) (See Table 1 for measurement of $W C A$ ). For revenue shifting, following Malikov et al. (2018), we use two alternative specifications for model (3). First, we exclude accounts receivable because they may contain receivables from non-operating revenues. Second, we replace account receivables with the cost of goods sold, as revenue shifting merely overstates operating revenue without affecting sales volume. The analysis (untabulated) confirms our main results for COGS misclassification and suggests that our findings are not sensitive to the specification of the gross profits and operating revenue expectation model.

\section{Conclusion}

Prior studies on gross profit manipulation document that firms engage in shifting of COGS to operating expenses, and to income-decreasing special items for reporting inflated gross profits. However, the shift of COGS to operating expenses does not serve the purpose of reporting inflated core earnings. Also, the shift of COGS to special items is not convenient for firms due to the non-recurring nature of special items. In India, the scope of expense shifting is relatively higher due to the vast categories of expenses in the income statement. Also, the Indian firms have strong incentives to meet analyst's core earnings forecasts. Hence, we posit that firms misclassify COGS as non-operating expenses which is easier and more beneficial to firms. It enables firms to inflate gross profit as well as core earnings. We also hypothesize that firms operating below the industry's average gross margin ratio are more likely to engage in expense shifting rather than revenue shifting due to its greater relative advantage in terms of stimulating profitability ratios. 
Our empirical results show that firms misclassify COGS as non-operating expenses for reporting inflated gross profits. Results also establish that firms with lower gross margin ratios are more likely to be engaged in expense shifting relative to revenue shifting for reporting inflated GMR. These findings have two important implications for firms. First, firms prefer to engage in shifting practices based on ease of shifting and multiple benefits. For instance, firms find it easy and more beneficial to shift COGS to non-operating expenses. Second, firm-specific factors influence firms to prefer one form of shifting over another. For instance, a firm with a lower GMR prefer one form of accounting gimmick (expense shifting) over other (revenue shifting) to meet peer performance.

This study contributes to the classification shifting literature, particularly to the literature on gross profit manipulation by highlighting that firms are more likely to shift COGS to non-operating expenses rather than operating expenses. Unlike prior studies on gross profit manipulations, this study controls the impact of other tools of earnings management which can be used to inflate gross profits. Overall, the current study adds to the growing interest in the shifting practices that seek to understand the specific accounts and accounting methods that managers use to manipulate earnings.

These findings have important implications for auditors who find it difficult to detect shifting practices as it merely overstates operating performance metrics, albeit net income remains unchanged. It suggests investors have a comprehensive review of items of financial statements while using these items in their portfolio valuation. It also suggests Indian standard-setting authorities make more detailed disclosure requirements for recording expenses and revenues items to curb this corporate misfeasance and ensure financial transparency.

The current suffers from the two main limitations. First, the limited availability of data to measure shifting practices of firms. Second, the study has been conducted under Indian institutional settings, hence the generalizability of the findings is the issue. Hence, future research can be conducted to examine the shifting practices under the different institutional frameworks to provide more robustness to the reported results. Future research can also be undertaken to identify the more firmspecific factors that incentivize firms to prefer one form of shifting over another. An examination of the impact of IFRS on shifting practices is also a future avenue of research.

\section{ENDNOTES}

Core earnings are defined as sales minus cost of goods sold (COGS) and selling, general, and administrative (SGA) expenses.
Gross profits are defined as sales minus COGS.

Fortune July 19, 2013; Barron's July 22, 2013; Forbes July 23, 2013.

4 Operating profits and core earnings have been interchangeably used in the study.

\section{REFERENCES}

Abernathy, J. L., Beyer, B. \& Rapley, E. T. 2014. Earnings management constraints and classification shifting. Journal of Business Finance and Accounting 41(5): 600-626.

Alfonso, E., Cheng, C. A. \& Pan, S. 2015. Income classification shifting and mispricing of core earnings. Journal of Accounting, Auditing and Finance.

Al-Haddad, L., Gerged, A. \& Saidat, Z. 2019. Managing earnings using classification shifting: Novel evidence from Jordan. Academy of Accounting and Financial Studies Journal 23(2): 1-14.

Al-Jaifi, H. A. 2017. Ownership concentration, earnings management and stock market liquidity: Evidence from Malaysia. Corporate Governance 17(3): 490-510.

Athanasakou, V. E., Strong, N. C. \& Walker, M. 2009. Earnings management or forecast guidance to meet analyst expectations? Accounting and Business Research 39(1): 3-35

Athanasakou, V., Strong, N. C. \& Walker, M. 2011. The market reward for achieving analyst earnings expectations: Does managing expectations or earnings matter? Journal of Business Finance \& Accounting 38(1-2): 58-94.

Bansal, M. \& Garg, A. 2021. Do high-quality standards ensure higher accounting quality? A study in India. Accounting Research Journal.

Bansal, M. \& Kumar, V. 2021. Forcing responsibility? Examining earnings management induced by mandatory corporate social responsibility: Evidence from India. Review of Accounting and Finance 20(2): 194-216.

Bansal, M., Kumar, A. \& Badhani, K. N. 2021. Do Indian firms engage in classification shifting to report inflated core earnings? Managerial Finance.

Bansal, M. \& Ali, A. 2021. Differential impact of earnings management on the accrual anomaly. Journal of Asset Management: 1-14.

Barnea, A., Ronen, J. \& Sadan, S. 1976. Classificatory smoothing of income with extraordinary items. The Accounting Review 51(1): 110-122.

Barua, A., Steve, L. \& Sbaraglia, A. M. 2010. Earnings management using discontinued operations. The Accounting Review 85(5): 1485-1509.

Behn, B. K., Gotti, G., Herrmann, D. \& Kang, T. 2013. Classification shifting in an international setting: Investor protection and financial analysts monitoring. Journal of International Accounting Research 12(2): 27-50.

Brown, L. D. \& Sivakumar, K. 2003. Comparing the value relevance of two operating income measures. Review of Accounting Studies 8(4): 561-572.

Chen, W., Hribar, P. \& Melessa, S. 2018. Incorrect inferences when using residuals as dependent variables. Journal of Accounting Research 56(3): 751-796.

Cheng, C. S., Liu, C. \& Thomas, W. 2012. Abnormal accrual estimates and evidence of mispricing. Journal of Business Finance \& Accounting 39: 1-34. 
Cready, W., Lopez, T. J. \& Sisneros, C. A. 2010. The persistence and market valuation of recurring nonrecurring items. The Accounting Review 85(5): 1577-1615.

Dechow, P. M., Sloan, R. G. \& Sweeney, A. P. 1995. Detecting earnings management. Accounting Review 70(2): 193-225.

DeFond, M. L. \& Hung, M. 2003. An empirical analysis of analysts' cash flow forecasts. Journal of Accounting and Economics 35(1): 73-100.

Fairfield, P. M., Sweeney, R. J. \& Yohn, T. L. 1996. Accounting classification and the predictive content of earnings. Accounting Review 23: 337-355.

Fan, Y. \& Liu, X. K. 2017. Misclassifying core expenses as special items: Cost of goods sold or selling, general, and administrative expenses? Contemporary Accounting Research 34(1): 400-426.

Fan, Y., Barua, A., Cready, W. M. \& Thomas, W. B. 2010. Managing earnings using classification shifting: Evidence from quarterly special items. The Accounting Review 85(4): 1303-1323.

Fan, Y., W. B. Thomas \& X. Yu. 2019. The impact of financial covenants in private loan contracts on classification shifting. Management Science 65(8): 3637-3653.

Gunny, K. A. 2010. The relation between earnings management using real activities manipulation and future performance: Evidence from meeting earnings benchmarks. Contemporary Accounting Research 27(3): 855-888.

Haw, I. M., Ho, S. S. \& Li, A. Y. 2011. Corporate governance and earnings management by classification shifting. Contemporary Accounting Research 28(2): 517-553.

Healy, P. M. \& Wahlen, J. M. 1999. A review of the earnings management literature and its implications for standard setting. Accounting Horizons 13(4): 365-383.

Klein, A. 2002. Audit committee, board of director characteristics, and earnings management. Journal of Accounting and Economics 33(3): 375-400.

Kolev, K., Marquardt, C. A. \& McVay, S. E. 2008. SEC scrutiny and the evolution of non-GAAP reporting. The Accounting Review 83(1): 157-184.

Kothari, S. P., Leone, A. J. \& Wasley, C. E. 2005. Performance matched discretionary accrual measures. Journal of Accounting and Economics 39(1): 163-197.

Lail, B. E., Thomas, W. B. \& Winterbotham, G. J. 2014. Classification shifting using the "corporate/other" segment. Accounting Horizons 28(3): 455-477.

Leuz, C., Nanda, D. \& Wysocki, P. D. 2003. Earnings management and investor protection: An international comparison. Journal of Financial Economics 69(3): 505-527.

Malik, S. A. \& Ahmad, A. C. 2017. Auditor tolerance of accrualbased and real earnings management in boardrooms of politically connected Nigerian firms. Asian Journal of Accounting and Governance 8: 101-111.

Malikov, K., Coakley, J. \& Manson, S. 2019. The effect of the interest coverage covenants on classification shifting of revenues. The European Journal of Finance 25(16): $1572-1590$

Malikov, K., Manson, S. \& Coakley, J. 2018. Earnings management using classification shifting of revenues. The British Accounting Review 50(3): 291-305.

McVay, S. E. 2006. Earnings management using classification shifting: an examination of core earnings and special items. The Accounting Review 81(3): 501-531.
Nagar, N. \& Sen, K. 2016. Earnings management in India: Managers' fixation on operating profits. Journal of International Accounting, Auditing and Taxation 26: 1-12.

Nagar, N. \& Sen, K. 2017. Classification shifting impact of firm life cycle. Journal of Financial Reporting and Accounting 15(2):180-197.

Narayanaswamy, R., Raghunandan, K. \& Rama, D. V. 2012. Corporate governance in the Indian context. Accounting Horizons 26(3): 583-599.

Noh, M., Moon, D. \& Parte, L. 2014. Earnings management using revenue classification shifting- Evidence from the IFRS adoption period. International Journal of Accounting and Information Management 25(2): 333-355

Poonawala, S. H. \& Nagar, N. 2019. Gross profit manipulation through classification shifting. Journal of Business Research 94: 81-88

Revsine, L., Collins, D. W. \& Johnson, W. B. 2005. Financial Reporting and Analysis. New Jersey: Prentice Hall.

Roychowdhury, S. 2006. Earnings management through real activities manipulation. Journal of Accounting and Economics 42(3): 335-370.

Shah, S. F., Rashid, A., Malik, W. S. \& Shahzad, F. 2020. Does ownership structure improve financial reporting quality? Evidence of real earnings manipulation among Pakistani firms. Asian Journal of Accounting and Governance 14: 37-51.

Sivanandan, P. \& Wahab, N. S. A. 2020. Mediating effects of remuneration on earnings management and firm equity value. Asian Journal of Accounting and Governance 14: $1-13$.

Watts, R. L. \& Zimmerman, J. L. 1990. Positive accounting theory: A ten year perspective. Accounting Review 65(1): 131-156.

Weygandt, J. J., Kieso, D. E. \& Kimmel, P. D. 2005. Financial Accounting. New York: John Wiley \& Sons Incorporated.

Yamaguchi, T. 2020. Earnings management to achieve industryaverage profitability in Japan. Asia-Pacific Journal of Accounting \& Economics: 1-30.

Zalata, A. \& Roberts, C. 2016. Internal corporate governance and classification shifting practices: An analysis of UK corporate behavior. Journal of Accounting, Auditing \& Finance 31(1): 51-78.

Zang, A. Y. 2012. Evidence on the trade-off between real activities manipulation and accrual-based earnings management. The Accounting Review 87(2): 675-70

Manish Bansal

Faculty of Accounting and Finance

Indian Institute of Management Ranchi

Meur's Road, Ranchi - 834 008Ranchi

INDIA.

E-mail:manish.bansal@iimranchi.ac.in

\section{ApPENDICES}

OPERATING EXPENSES EXPECTATION MODEL

Following Gunny (2010), we model operating expenses $(O E)$ to determine the expected level of $O E$. The unexpected $O E$ is measured as residual from the following model (1) 


$$
\begin{aligned}
O E_{i, t}= & \gamma_{0}+\gamma_{1} \frac{1}{\text { Assets }_{i, t-1}}+\gamma_{2} O E_{i, t-1} \\
& +\gamma_{3} M V_{i, t}+\gamma_{4} \text {Tobin }_{i, t}+\gamma_{5} I N T_{i, t} \\
& +\gamma_{6} \Delta \text { Sales }_{i, t}+\gamma_{7} \text { Neg_dSales }_{i, t}+\varepsilon_{i, t}
\end{aligned}
$$

Where $O E$ is operating expenses. $M V$ is a proxy for firm size. Tobin $Q$ is a measure of growth used to control for net benefits to new investments. INT is a proxy for controlling internally funds.

\section{MEASUREMENT OF REM AND AEM}

We Roychowdhury (2006) model to measure real earnings management (REM). Following these studies, we use three proxies, namely abnormal level of cash flows from operations $\left(A_{-} C F O\right)$, abnormal level of discretionary expenses $\left(A_{-} D I S X\right)$, an abnormal level of production cost (A_PROD) measured as residuals from following models (2), (3) and (4). We employ a performance-adjusted modified Jones (1991) model (Kothari et al. 2005) for computing abnormal level of accruals, measured as residual from following mode 1 (5):

$$
\begin{aligned}
& \frac{C F O_{i, t}}{A T_{i, t-1}}=\alpha_{0}+\beta_{1} \frac{1}{A T_{i, t-1}}+\beta_{2} \frac{S_{i, t}}{A T_{i, t-1}}+\beta_{3} \frac{\Delta S_{i, t}}{A T_{i, t-1}}+\varepsilon_{i, t} \\
& \frac{D I S X_{i, t}}{A T_{i, t-1}}=\alpha_{0}+\beta_{1} \frac{1}{A T_{i, t-1}}+\beta_{2} \frac{S_{i, t-1}}{A T_{i, t-1}}+\varepsilon_{i, t} \\
& \frac{P R O D_{i, t}}{A T_{i, t-1}}=\alpha_{0}+\beta_{1} \frac{1}{A T_{i, t-1}}+\beta_{2} \frac{S_{i, t}}{A T_{i, t-1}}+\beta_{3} \frac{\Delta S_{i, t}}{A T_{i, t-1}} \\
& +\beta_{4} \frac{\Delta S_{i, t-1}}{A T_{i, t-1}}+\varepsilon_{i, t} \\
& \frac{A C C_{i, t}}{T A_{i, t-1}}= \\
& \emptyset_{1}\left(\frac{1}{T A_{i, t-1}}\right)+\emptyset_{2} \frac{(\Delta R E V-\Delta R E C)_{i, t}}{T A_{i, t-1}} \\
& +\emptyset_{3} \frac{P P E_{i, t}}{T A_{i, t-1}}+\emptyset_{4} R O A_{i, t}+\varepsilon_{i, t}
\end{aligned}
$$

Where $C F O$ is cash flow from operations, $A T$ is assets, $S$ is sales, $\triangle \mathrm{S}$ is change in sales, DISX is discretionary expenses, $P R O D$ is production costs. $A C C$ denotes the total accruals. $\triangle R E V$ is change in firm's revenue from operations; $\triangle R E C$ is changed in receivables; $P P E$ represents property, plant, and equipment; $R O A$ is net income divided by the total assets. 